\title{
USING MOBILE APPLICATIONS AS A MARKETING TOOL IN AGRIBUSINESS
}
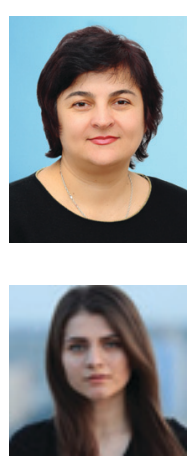

O. I. BABICHEVA, PhD in Economics, Associate Professor

Department of Marketing and International Trade, National University of Life and Environmental Sciences of Ukraine ORCID ID: 0000-0003-3786-0226

E-mail: helenmark044@gmail.com

O.V. HAVRYLIUK, master of Marketing, National University of Life and Environmental Sciences of Ukraine

ORCID ID: 0000-0003-4365-3143

E-mail:olga39516@gmail.com

Abstract: Studies have been conducted on current problems and prospects of using mobile Apps in Ukrainian agriculture. The mobile application market for agricultural businesses is analyzed along with their main features and benefits. The main limiting factors for the use of mobile applications in the agrarian sector of Ukraine are identified. The positive changes that are expected in this area as a result of the development of a national program for the introduction of digital services in the country, the development of infrastructure and the spread of high-speed mobile communication have been noted. Mechanisms of functioning of mobile applications as a marketing tool are defined. The main marketing goals of using the Mobile App in the agricultural sector, as well as the stages of their introduction to the market are highlighted. The basic types of mobile applications for different platforms, their advantages and disadvantages, evaluation and selection criteria are described. Examples of software products that are implemented as marketing tools for promoting food products, as well as products and services for agriculture that can be used to support management decisions in agribusiness. The multi-purpose nature of mobile applications be emphasized, which become a competitive advantage of the company and not only increase customer loyalty, that receive useful information and practical management tools, but also provide growth of sales and formation of stable partnerships.

Keywords: mobile applications, Internet penetration, marketing tools, marketing objectives of mobile applications

\section{Introduction.}

In Ukraine, like in most developing countries, the share of agriculture in the gross national product is large $(11.9 \%$ in 2018), but it is also an export-oriented industry, which provides up to $40 \%$ of the country's foreign exchange earnings[1].. In conditions of transition to the innovative-information econo- 
my, global hyper-competition in agricultural markets, increasing consumer awareness and expectations about the range and quality of products, the use of modern information technologies and innovations by Ukrainian agribusiness is especially relevant.

The rapid development of mobile Internet creates a new informational global reality. According to N.A. Krahmalova, growing competition in the world market motivates companies to use an innovative approach in forming a positive consumer experience: developing mobile applications for smartphones and tablets, creating websites with adaptive design to establish mobile sales channels [5].

Today one of the most promising is the mobile application market, which is characterized by active development. Mobile applications are opening up new channels of communication and opportunities to enter the agricultural business, potentially offering greater access to public information and essential services. Using the popularity, convenience and modernity of the latest inventions of information technology, marketers have begun to particularly promote them, as professional tools for specialists in various industries.

The urgent need to create favorable economic and organizational conditions for improving the efficiency of the agricultural sector is the use of a wide range of IT solutions, including: GIS technologies, GPS navigation, CRM and HRM systems, ERP strategies, telemetry. The growing popularity of smartphones is driven by the increasing number of advantages over desktop PCs. Various aspects of usage of mobile applications in business and agrarian sphere are covered in many foreign sources $[4,6,10$, $13,17]$. A special place is occupied by the study of usage of mobile applications particularly in developing countries $[6,21]$.

\section{Analysis of recent research and publications.}

Unfortunately, in Ukrainian publications this issue is paid very little attention. The principles of mobile marketing were discussed in publications Bugaev L., Ezhov A, Lubko D.V. , prospects for the development of mobile marketing Babkov VY, Polintsev PV, Ustyuzhanin VI, Bazarov R., Orlov V.N. Prerequisites for the development of mobile marketing including mobile applications in agricultural enterprises covered in publications of Shvidenko O.M. [18, 20].

However, despite the large number of publications describing the technical characteristics of mobile applications, further research is needed regarding the effectiveness of their use in agriculture.

\section{The purpose of the research.}

a. Clarify the meaning of the concept of "mobile application";

b. Analyze the market of mobile applications for agricultural enterprises and their main characteristics;

c. Describe the main types of mobile systems and mobile application development tools for different platforms;

d. Determine the structure, functional significance, principles of using and features of the main stages of mobile applications.

\section{Materials and methods of research.}

The theoretical and methodological basis of the study is the system of general scientific and special methods, name- 
ly: methods of comparison and systematization, synthesis and analysis (in clarifying the essence of the definition of "mobile application"); observing, comparing documents, interviewing (finding out the most commonly used development tools and types of mobile applications for agribusiness).

\section{The results of the research and their discussion.}

In today's innovative society, all entities are using different mobile devices and applications that provide up-to-date data. Mobile applications allow to effectively integrate information with social networks, business websites, multimedia content and communication media. They are actively implemented by agrarian enterprises and greatly facilitate the work in calculations, field characteristics, work planning. The results of the study make it possible to determine that the mobile application is a standalone software designed to work on smartphones, tablets and other mobile devices, which is installed through the markets: portals, shops, marketplaces in order to optimize and solve user problems.

The global market for mobile applications is one of the fastest growing. According to Statista Analytical Bureau [1], in 2019 consumers downloaded 204 billion mobile apps to their connected devices, up from 140.7 billion app downloads in 2016.

In Ukraine, the situation is not promising, because there are there are not enough a mobile applications oriented specifically on the Ukrainian market. Most mobile application development companies work with customers from the United States, Canada, and Israel.

There are several factors that contribute to this situation:
1. Absence of $3 \mathrm{G} / 4 \mathrm{G}$ networks of new generation in Ukraine, therefore mobile Internet is very slow and quite expensive. Using most services in such conditions is not possible.

2. The Ukrainian IT market is mainly outsourced, which means that most developers write software for foreign companies and are not focused on creating domestic products. There are many IT companies, however mainly oriented on the western market.

3. Ukrainian business is rather conservative, but the main obstacle is low computer grammaticality especially in agriculture and underestimation of the capabilities of IT technologies. Ukrainian business is still arguing why mobile applications are needed, struggling with creation of a mobile version for the website, and, at best, create a responsive design for their sites. Those businesses that have released mobile applications have done so, rather, on the principle of "to be", and, as a rule, these applications are a "complement" to the main service. In addition, a low competition in the market plays an important role, since companies do not think much about loyalty programs or retaining existing customers, where the use of mobile technologies is justified and efficient.

4. The price of developing a mobile application has long been commensurate with the price of developing a website. Considering that there are several main mobile platforms (iOS / Android / Windows Phone / Windows 8), and system updates come out often enough, the development and support costs are high, therefore most companies cannot afford to develop applications at western prices. 
5. The legislation in the field of currency control does not allow simple and transparent work and pay taxes on the sale of mobile applications through stores - Google Play, Apple Store, Windows Phone Store and Windows Store. For many developers, this is a huge hurdle. If you remove these restrictions, many developers will begin to upload their own applications in the appropriate stores and make money on them [19].

After the introduction of $3 \mathrm{G} / 4 \mathrm{G}$ technologies, e-government and other initiatives related to the automation and informatization of the city, utilities and other services, it is likely that the domestic market will gradually begin to build up.

In addition to the benefits of using mobile applications for the development of the agricultural sector that were defined by the World Bank [9], they also enable achieving the marketing goals of stakeholders.

Among the most widely used types for business and customers are the following: process automation; productivity increasement, collaboration; an ex- tension of on-line services and mobile applications as a regular customer card. It is argued that the key benefit of using mobile apps for entrepreneurs is the ability to retarget which involves creating a strong brand and expanding their markets by analyzing buyer behavior and reminding them of completed tasks with push notifications, using customer preferences based on search and purchase history for advertising, geolocation services integration, integration with social networks. The mobile application as one of the main information channel of the enterprise provides: prompt access to data for users of any level; wireless two-way communication with technological equipment and information system; receiving up-to-date information in real time; quick decision-making.

Today, there are several approaches to the technical implementation of mobile applications, namely: native, hybrid, progressive (PWA) [15]. Their main characteristics are presented in table 1. As can be seen from Table 1, while native applications have more advantages.

\section{Table 1. Comparative characteristics of the main types of mobile applications}

\begin{tabular}{|l|c|c|c|}
\hline & Native & Hybrid & PWA \\
\hline $\begin{array}{l}\text { Ability to reuse } \\
\text { code }\end{array}$ & $\begin{array}{c}\text { The code is developed } \\
\text { separately for each platform }\end{array}$ & $\begin{array}{c}\text { Code reuse is } \\
\text { possible }\end{array}$ & $\begin{array}{c}\text { Code reuse is } \\
\text { possible }\end{array}$ \\
\hline $\begin{array}{l}\text { Access to device } \\
\text { features }\end{array}$ & The most complete & Limited access & Very low \\
\hline Distribution model & App Store Downloads & $\begin{array}{c}\text { App Store } \\
\text { Downloads }\end{array}$ & URL access \\
\hline Productivity & High & Low & Low \\
\hline Device support & High & High & Average \\
\hline $\begin{array}{l}\text { Support for } \\
\text { external libraries }\end{array}$ & High & Average & High \\
\hline Popularity & High & Average & Average \\
\hline
\end{tabular}

Source: Created by the author based on [7] 
Table 2. Comparative characteristics of mobile operating system development tools

\begin{tabular}{|l|c|c|c|c|}
\hline & Apple iOS & Android & Blackberry OS & Windows Phone \\
\hline $\begin{array}{l}\text { Programming } \\
\text { language }\end{array}$ & $\begin{array}{c}\text { Objective- } \\
\text { C,C++, Swift }\end{array}$ & Java, Kotlin & Java & C\#, VB.NET \\
\hline $\begin{array}{l}\text { Development } \\
\text { tools }\end{array}$ & Xcode & Android SDK & $\begin{array}{c}\text { BB Java Eclipse } \\
\text { Plugin }\end{array}$ & $\begin{array}{c}\text { Visual Studio, Phone } \\
\text { development tools }\end{array}$ \\
\hline Packing format & .app & .apk & .cod & .xap \\
\hline Shop & $\begin{array}{c}\text { Apple App } \\
\text { Store }\end{array}$ & Google Play & $\begin{array}{c}\text { Blackberry App } \\
\text { World }\end{array}$ & $\begin{array}{c}\text { Windows Phone } \\
\text { Marketplace }\end{array}$ \\
\hline
\end{tabular}

Source: Created by the author based on [3]

The development of separate applications for different mobile operating systems is characterized by high costs of time and resources, since each of them is based on a separate programming language and requires specific features.

The comparative characteristics of mobile application development tools for different platforms are shown in Table 2.

The regional difference in the cost of applications is related to the differentiation of the pay of programmers (Figure 1.). The cost of native applications differs slightly. IOS exceeds the cost of Android by region within 0-8,3\%.
However, since about $1 / 4$ of the market is iOS, for more market coverage companies have to create 2 applications. In this case hybrid cross-platform development takes an average of $55.2-66.7 \%$ less cost than concurrent native development of individual Android and iOS applications.

Among the key benefits of hybrid mobile applications and progressive applications are the following:

Economic efficiency. Developing one application at a time for multiple software platforms reduces the cost of resources and time. The use of such

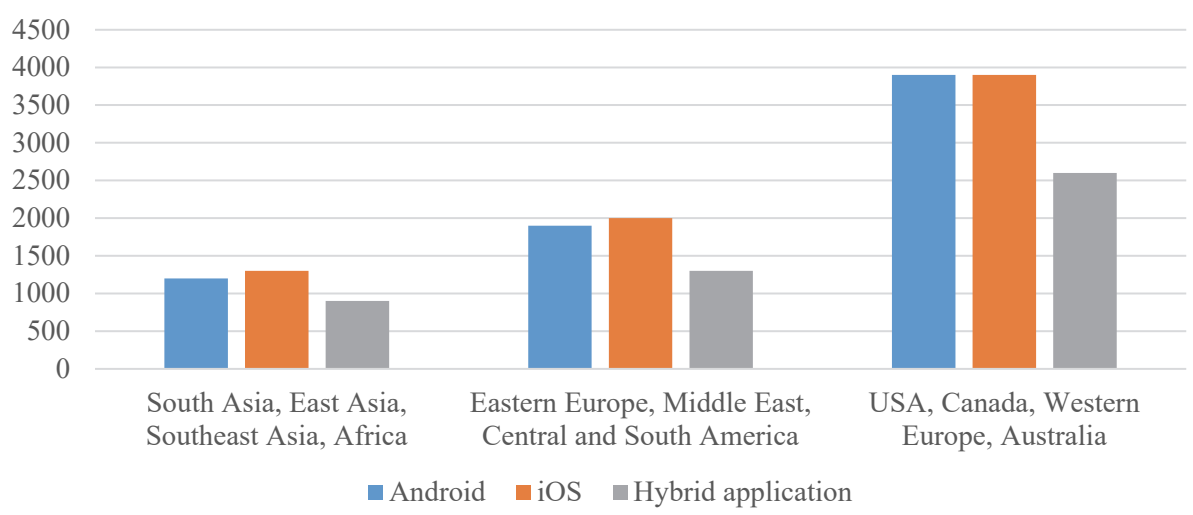

Figure 1. Comparison of the cost of developing mobile applications for different operating systems, USD USA.

Source: Created by the author based on [11] 
technologies greatly facilitates the process of updating and adding new functionality for all devices at the same time without discriminating;

Easy to develop and use tools (HTML, CSS and JavaScript), access to free libraries, plugins, and frameworks. In today's environment, any web developer can create a hybrid mobile application or a progressive web application without the need to learn additional technologies;

Use without internet access. The use of storage device APIs locally is an essential necessity for users with a slow internet connection;

User-friendly interface, most similar to native;

Quick installation. PWAs, unlike native applications, do not require installation on the device, but are added directly from the browser.

In addition, an analysis of statistics on the use of PWAs compared to traditional websites shows: increased mobile traffic; multiple downloads and installs of the application $25 \mathrm{x}$ weight reduction of the application in the device memory; a $52 \%$ increase in average conversion, $137 \%$ conversion rate, $133.67 \%$ page views continuation of the average session by $78 \%$; lower bounce rate compared to mobile websites by $42.86 \%$ [7].

However, the main disadvantage of progressive web applications is the lack of device support. It is also worth noting the limitations for PWA on Apple iOS compared to native and hybrid applications like: support starting with iOS 11.3; storage of local data and files up to $50 \mathrm{MB}$; deletion of data in the case of long-term non-use; lack of access to much of the native features, code execution in the background, personal information, much of Apple's services, push notifications and Siri integration. In our opinion, these PWA restrictions are a major drawback for Apple iOS users, who are an important part of the target audience of Ukrainian entrepreneurs, as this segment is traditionally considered to be more solvent than Android and Windows Phone users.

Factors that affect the positive dynamics of the growth of the mobile application market and arouse the interest of many modern companies:

- An increase in the number of mobile devices, including tablet computers;

- More accessible communication through mobile devices;

- Development of mobile banking;

- The growing popularity of GPS navigation [5].

The analysis shows that mobile app creation goals are unlike for different types of enterprises. Large Agro holdings often create bespoke applications that integrate with existing information systems to address corporate governance issues: improving internal communications and operational management, simplifying accounting, logistics, and more.

IT companies offer agrarian manufacturers mobile applications on a commercial basis for a wide range of tasks. For example, the Ukrainian developer QuartSoft Ltd offers the application Soft.Farm Eye-Agronomist for crop production (to accelerate the work is divided into 3 parts today: Agroscouting, Field work, GPS Fields), which allows to conduct field surveys, assessment of phytosanitary status of crops and assembly agronomist reports; to conduct planning and accounting of field work and GPS measurement of land areas. For livestock is a Rabbits application that allows you to plan and account for livestock. Cadaster UA app allows one to determine the boundaries of land plots on the terrain using a cadastral 
map of Ukraine, to measure the actual area of units and to create a land bank of the economy.

There is an active increase in the supply of free agrarian applications by suppliers of material and technical resources: machinery and spare parts, fertilizers, plant protection products, seeds. These add-ons are filled with useful content and features for consumers, aimed at promoting and increasing product sales, maintaining productive relationships and loyalty for their customers. Popular applications from such companies as BASF, Singenta, Adama, DuPont Pioneer, August-Ukraine, UkraVit, John Deer and others. Some companies have multiple applications with different functionality to solve different consumer tasks and optimize application performance. Yes, Adama offers 3 free applications: Adama 2020 - Catalog of plant protection products, Adama Lab - electronic determinant of diseases, weeds, pests and professional advice of an independent specialist in their elimination, Adama Fin - monitoring domestic, world prices of basic agricultural crops and their forecast, elevator map and cost of their services, commercial terms of cooperation with ADAMA. This app allows the farmer to analyze market trends, compare possible alternatives, and make informed decisions about agricultural sales.

There is less widespread use of agrarian producers` mobile applications aimed at maintaining consumer loyalty. Such applications began to be introduced by processing companies.

The competitive advantage in the dairy market in Ukraine for the brand Molokiya was the development of the mobile application "Kazkovyy". With the introduction of the mobile app and large-scale national advertising, brand awareness increased 2.5 times [1].The application is available in all services and with the help of a scan of milk packaging. User can then create its own character and customize accordingly.

Factors that contributed to the positive dynamics of mobile app demand growth:

- Integration of old Ukrainian fairytale characters, namely: Mavki, Kotygoroshok, Ivasik Telesik, who tell interesting and informative stories.

- The interactive part that includes puzzles and quests

- Design created for the kid who is the main user of the mobile application

- Adaptability. Download speed and adaptability of mobile application in different format.

\section{Conclusion.}

In today's innovative society, virtually all entities use different mobile devices and applications that provide up-to-date data. Mobile applications enable to effectively integrate information with social networks, business sites, multimedia content and communication media. They are actively implemented by agrarian enterprises and greatly facilitate the process of calculation, field characteristics, work planning. The multi-purpose nature of mobile applications be emphasized, which become a competitive advantage of the company and not only increase customer loyalty, that receive useful information and practical management tools, but also provide growth of sales and formation of stable partnerships.

The analysis made it possible to determine that hybrid cross-platform development is the most optimal method, which requires an average of $66.7 \%$ less 
cost than the simultaneous native development of separate applications for Android and iOS. Key advantages include: cost-effectiveness, ease of development and use of tools, use without internet access, user-friendly user interface, quick installation.

\section{References}

1. Agro Online Official Website. - Available: https: //agro-online.com.ua

2. Annual number of global mobile app downloads 2017-2022 [Electronic resource] // Statista. - 2019. - Available: https://bit. ly/2zTtudv.

3. Average Time Spent Per Day With Mobile Internet Among US Adults, In-App Vs. Mobile Web, 2015-2019 [Electronic resource] // eMarketer. - 2017. - Available: bit.ly/2IKBO5B.

4. Chhachhar A. The Use of Mobile Phone Among Farmersfor Agriculture Development Chhachhar, M. Hassan // International journal of scientific research. 2013. - Available: https://www.academia. edu/4820382/ Research_Paper_The_Use_ of_Mobile_Phone_Among_Farmers_for_ Agriculture_Development.

5. Developing a hybrid mobile application with lonic - Available: bit.ly/2VYGNQH.

6. e-Agriculture-Available: http://www.e-agriculture.org/e-agriculture.

7. Global Commerce Review [Online Resource] - Available: https://bit.ly/2AkZ5Re

8. Internet penetration in Ukraine. Factum Group. October, 2019 Available:

https://inau.ua/sites/default/files/file/1910/ dani_ustanovchyh_doslidzhen_iii_kvartal_2019_roku.pdf

9. Kisil NM Classification of information systems / NM Kisil, ZP Gatalyak, NI Gorbal [Electronic resource] - Available: http://base.dnsgb.com.ua/files/ journal / Lisove-gospodarstvo-Ip-dpromyslovist / 2004_29 / 242_Kysil_LG_29.pdf
10. Lonoff Schiff J. 6 Mobile Marketing Trends to Leverage in 2014 . - 2013. - Available: tp://www.cio.com/article/2379960/mobile-apps/6-mobile-marketing-trends-toleverage-in-2014.html.

11. Lubko DV Design methodology and tools for creating mobile applications Visnyk Nat. tech. Univ "KPI": coll. Sciences. Theme. vol. : New solutions in modern technologies. Kharkiv: NTU "KPI". - 2013. - No. 56 (1029). - pp. 117-122.

12. mAgri - Available: http://www.gsma.com/ mobilefordevelopment/ programmes/magri.

13. Marrs M. What is Mobile Marketing and Why Does it Matter? - 2013. - Available: http://www.wordstream.com/blog/ ws/2013/08/19/what-is-mobile-marketing.

14. Mobile Operating System Market Share Ukraine [Electronic resource] - Available: bit.ly/2HyPdKr.

15. Official site of AgroController [Electronic resource]. - Available: https://agro.controler.ua

16. Precision Agriculture: 6 Mobile Use Trends To Watch [Electronic resource]. - 2014.

- Available: http://www.croplife.com/ editorial/matt-hopkins/precision-agriculture-6-mobile-use-trends-towatch/? utm_source=knowledgemarketing\&utm_ medium=newsletter\&utm_campaign= clenews\%2003262014.

17. Roberts, G. McIntosh. Use of mobile devices in extension and agricultural productiona case study. K. 2012. - Available: http:// www.regional.org.au/au/asa/2012/precision-griculture/8224_robertsk.htm.

18. Shvydenko O.M. Prerequisites for the development of mobilemarketing in agricultural enterprises. "The Economy of Agro-Industrial Complex" International Scientific and Production Journal. 2014, №11 p.114-119.

19. Soft.Farm Eye Official Website - Agronomist. - Available: :https://play.google.com/ store/apps/details?id=farm.soft\&hl=en

20. Strategy of development of the agrarian sector of the economy of Ukraine for the period up to 2020 № 806-2013. from 10/17/2013. 
- Available: http://zakon2.rada.gov.ua/laws/ show/806-2013-\%D1\%80

21. Studying Mobile Apps for Agriculture Constantina Costopoulou, Maria Ntaliani,
Sotiris Karetsos. IOSR Journal of Mobile Computing \& Application (IOSR-JMCA) .Volume 3, Issue 6 (Nov. - Dec. 2016), PP 44-99 www.iosrjournals.org

Бабічева О.І., ГаврилюК О.В. (2019). ВИКОРИСТАННЯ МОБІЛЬНИХ ДОДАТКІВ ЯК ІНСТРУМЕНТУ МАРКЕТИНГУ В АГРАРНІЙ СФЕРІ. БІОЕКОНОНОМІКА ТА АГРАРНИЙ БІЗНЕС, 10(2): 5-13. http://doi.org//10.31548/bioeconomy2019.02.005

Анотація. В статті висвітлюються проблеми та перспектив використання мобільних додатків в українському сільському господарстві. Ринок мобільних додатків для сільськогосподарських підприємств аналізується разом з їх основними можливостями та перевагами. Визначені основні обмежуючі фактори використання мобільних додатків в аграрному секторі України. Визначено механізми функціонування мобільних додатків як маркетингового інструменту, маркетингові цілі та задачі їх використання, а також етапи впровадження на ринок. Описані основні типи мобільних додатків для різних платформ, їх переваги та недоліки, критерії оцінки та вибору. Наведені приклади програмних продуктів, що впроваджені як маркетингові інструменти просування продовольчих продуктів, а також товарів і послуг для сільського господарства, мають багатоцільовий характер і не лише збільшують лояльність споживачів, а й забезпечують зростання продажів та формування стійких партнерських відносин.

Ключові слова: мобільні додатки, проникнення Інтернет, маркетингові інструменти, маркетингові цілі мобільних додатків.

Бабичева Е.И., ГаврилюК О.В. (2019). ИСПОЛЬЗОВАНИЕ МОБИЛЬНЫХ ПРИЛОЖЕНИЙ В КАЧЕСТВЕ ИНСТРУМЕНТА МАРКЕТИНГА В АГРАРНОЙ СФЕРЕ. БІОЕКОНОНОМІКА ТА АГРАРНИЙ БІЗНЕС, 10(2): 5-13. http://doi.org//10.31548/ bioeconomy2019.02.005

Аннотация: В статье освещаются проблемы и перспективы использования мобильных приложений в украинском сельском хозяйстве. Рынок мобильных приложений для сельскохозяйственных предприятий анализируется вместе с их основными возможностями и преимуществами. Определены основные ограничивающие факторы использования мобильных приложений в аграрном секторе Украины. Определены механизмы функционирования мобильных приложений как маркетингового инструмента, маркетинговые цели и задачи их использования, а также этапы внедрения на рынок. Описаны основные типы мобильных приложений для различных платформ, их преимущества и недостатки, критерии оченки и выбора. Приведенные примеры программных продуктов, внедрены как маркетинговые инструменты продвижения продовольственных продуктов, а также товаров и услуг для сельского хозяйства, имеют многоцелевой характер и не только увеличивают лояльность потребителей, но и обеспечивают рост продаж и формирования устойчивых партнерских отношений

Ключевые слова: мобильные приложения, проникновение Интернета, маркетинговые инструменты, маркетинговые цели мобильных приложений. 